\title{
PREFACE
}

Educational institutions need to innovate education in order to meet human resource needs towards the Golden Indonesia 2045. Innovation in education needs to be grounded in the culture and character of the nation, developing literacy competencies, mastering technology, and being able to deal with changes in very fast and uncertain conditions (disruption era). To support this, education institutions need to study and share the results of research on education based on culture and character, literacy, technology, and the era of disruption in scientific forums. Therefore, Elementary School Teacher Education Program Sebelas Maret University as an educational institution initiated a scientific forum in the form of the National Seminar on Educational Innovation (SNIP 2018) with the theme "Culture-Based Education, Technology and Literacy in Facing the Disruption Era Towards Gold Generations 2045".

Golden Indonesia 2045 is referred to as the golden era of Indonesia, in that year Indonesia experienced a demographic bonus, where the number of productive population was more than the unproductive population. However, the golden age is not easy to achieve because of various challenges such as: (1) the character and culture of the Indonesian nation that previously held on to religious teachings, the noble values of the nation deteriorated; (2) the adverse effects of globalization are increasingly visible; and (3) changes in conditions that are very fast and uncertain (disruption era). Therefore, a step is needed to create a capable Indonesian gold generation of 2045 and able to face the era of disruption. One of them is through character education. In this seminar we will discuss about culture, technology and literacy-based education in the face of the era of disruption.

The objectives of SNIP 2018 are: (1) to build the same perception about the importance of culture-based education and technology and literacy; (2) build insight into the Golden Age of Disruption and Indonesia 2045; (3) preparing educators who are able to instill culture-based, technological and literacy education through learning innovations; (4) means of dissemination of the results of research and / or studies to the community and stakeholders; and (5) building synergies and partnerships nationally.

On this occasion, the committee expressed his gratitude and appreciation to the parties who participated in the success of this activity, namely: Prof. Dr. Joko Nurkamto, M.Pd. Dean of the Faculty of Teacher Training and Education, Sebelas Maret University Surakarta, which has given permission and ease in organizing seminars; Prof. Dr. Ir. Suhardjono, MPd., Dipl. HE. from Universitas Brawijaya, Prof. Dr.rer.nat. Sajidan, M.Sc. from Sebelas Maret University, Prof. Dr. Siti Irene Astuti Dwiningrum, M.Sc. from Yogyakarta State University, and Dr. Rokhmaniyah, M.Pd. from Sebelas Maret University as the keynote speaker; companion speakers; committee and students who have helped the activities from beginning to end, and all seminar participants who have participated actively in this activity.

Editor Proceeding SNIP 2018,

Dr. Suhartono, M.Pd.

Moh Salimi, M.Pd.

Ratna Hidayah, M.Pd. 


\section{LIST OF COMMITTEE}

\section{Steering Commitee}

Chairperson:

Prof. Dr. Joko Nurkamto, M.Pd.

Advisory Boards and Scientific Committee:

1. Dr. Munawir Yusuf, M.Psi.

2. Dr. Imam Sujadi, M.Si.

3. Dr. Sapta Kunta Purnama, M.Pd.

4. Dr. Suhartono, M.Pd.

5. Dr. Rokhmaniyah, M.Pd.

6. Drs. Wahyudi, M.Pd.

7. Drs. Muhammad Chamdani, M.Pd.

8. Drs. Joharman, M.Pd.

9. Dra. Tri Saptuti Susiani, M.Pd.

10. Kartika Chrysti Suryandari, M.Si.

11. Drs. Ngatman, M.Pd.

12. Moh Salimi, M.Pd.

13. Ratna Hidayah, M.Pd.

14. Drs. Suripto, M.Pd.

15. Drs. Imam Suyanto, M.Pd.

16. Siti Fatimah, M.Pd.

\section{Organizing Commitee}

Chairperson:

Drs. Muhammad Chamdani, M.Pd.

Secretarial staffs:

1. Dr. Rokhmaniyah, M.Pd.

2. Drs. Wahyudi, M.Pd.

3. Kartika Chrysti Suryandari, M.Si.

Accomodation and Ceremony:

1. Drs. Ngatman, M.Pd.

2. Drs. Imam Suyanto, M.Pd.

3. Dra. Tri Saptuti Susiani, M.Pd.

4. Siti Fatimah, M.Pd.

Papers and Publication:

1. Dr. Suhartono, M.Pd.

2. Moh Salimi, M.Pd.

3. Susi Apriati Madsar, M.Hum.

Website Development:

1. Ratna Hidayah, M.Pd.

2. Miftahus Salami, S.I.Kom.

Logistic and Supporting Team:

1. Drs. Joharman, M.Pd.

2. Drs. Suripto, M.Pd. 


\section{SEMINAR PHOTOGRAPH}
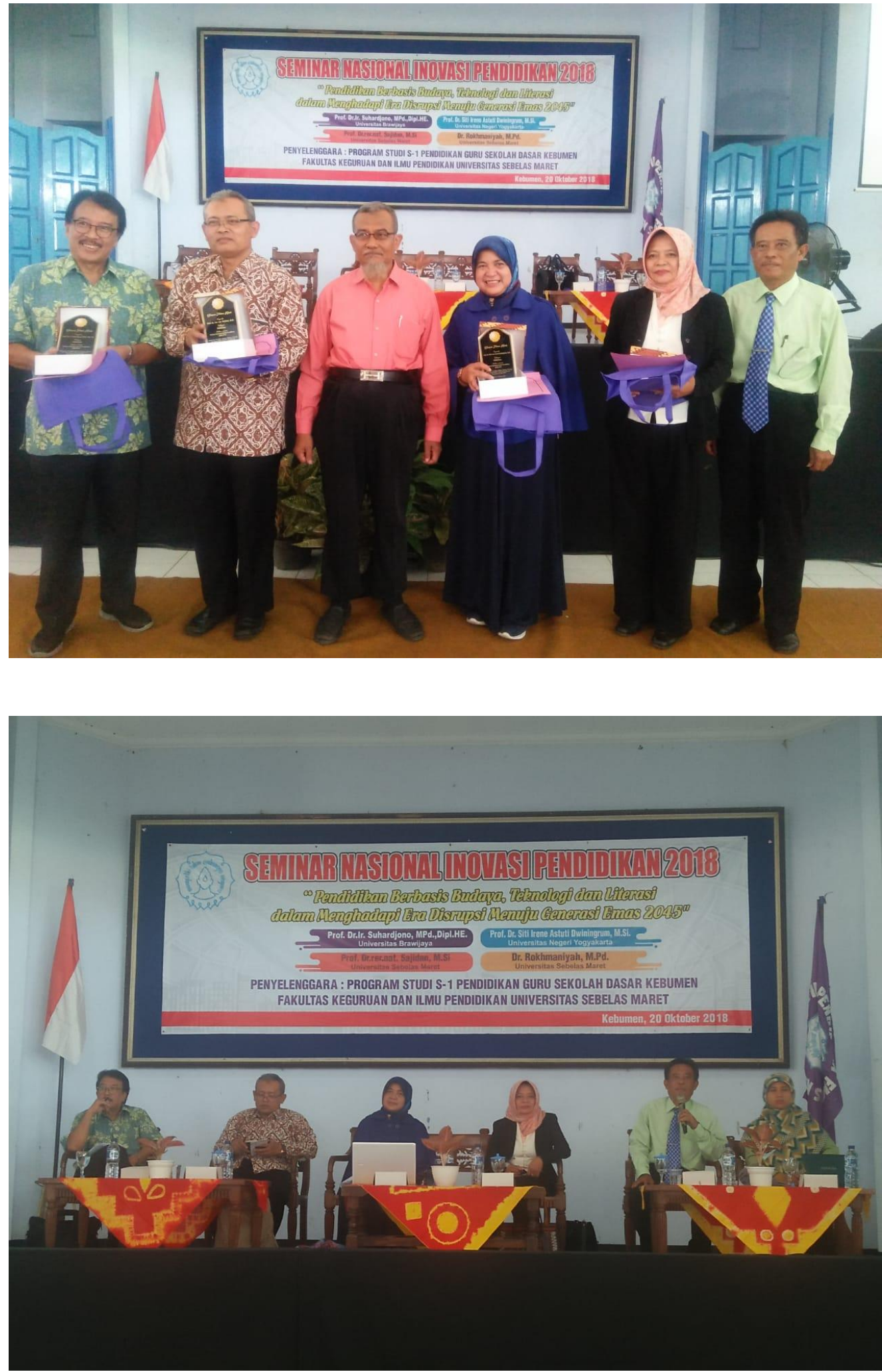

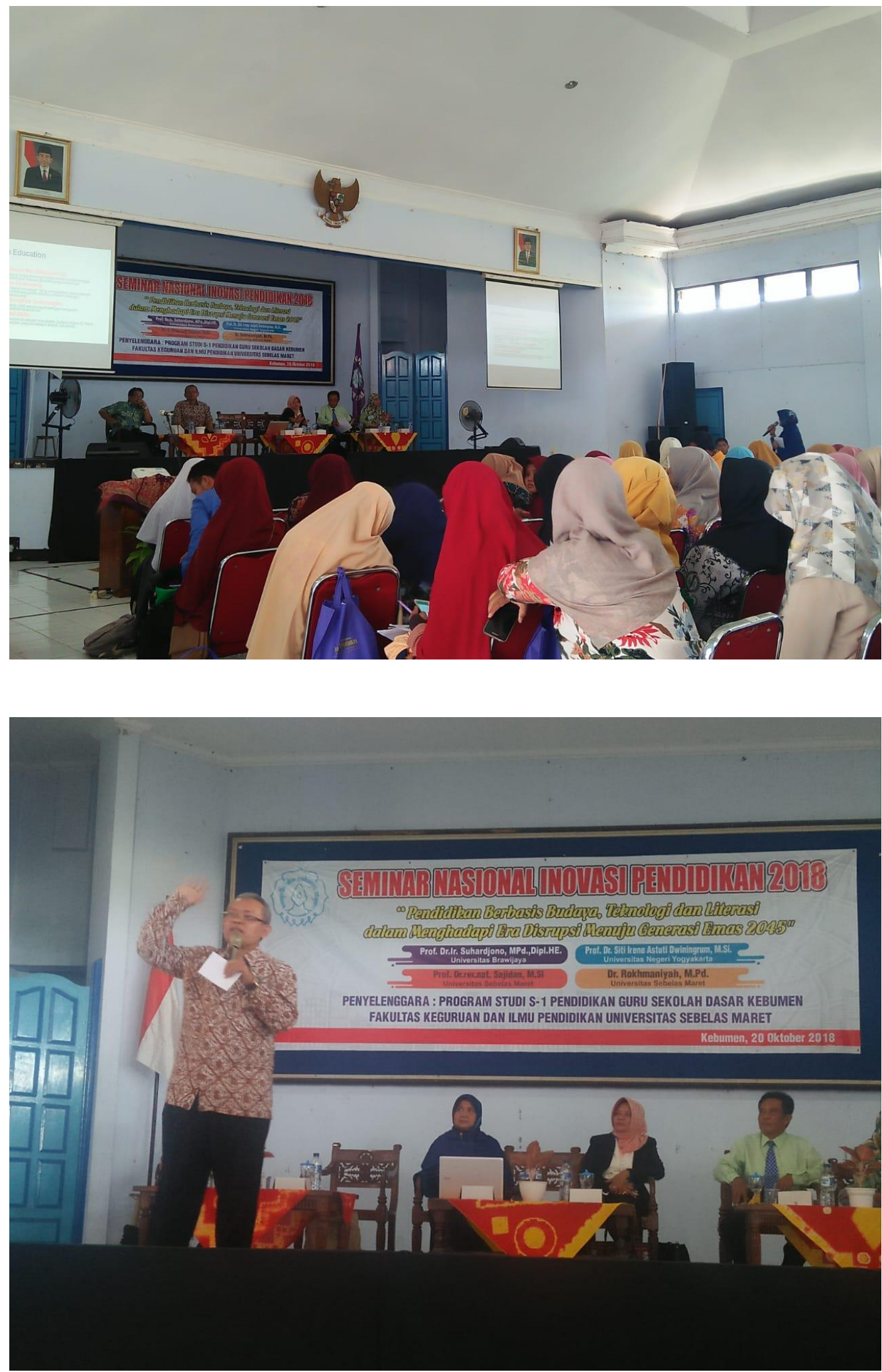
SHEs: Conference Series 1 (2) (2018) i-xii

\section{PEER REVIEW STATEMENT}

All papers published in this volume of Social, Humanities, and Educational Studies (SHEs): Conference Series have been peer reviewed through processes administered by the proceedings Editors. Reviews were conducted by expert referees to the professional and scientific standards expected of a proceedings journal published by Universitas Sebelas Maret. 


\section{TABLE OF CONTENTS}

\section{PREFACE}

LIST OF COMMITTEE

SEMINAR PHOTOGRAPH

PEER REVIEW STATEMENT

TABLE OF CONTENTS

ANALYSIS OF CHARACTER VALUES IN THE POETRY OF "LETTER FROM MOTHER" WORKS ASRUL SANI AND "UNKNOWN HEROES" WORKS TOTO SUDARTO BACHTIAR

Rokhmaniyah

HIGH LEVEL THINKING SKILLS EMPOWER STUDENTS PRIMARY 9-19 EDUCATION THROUGH INNOVATIVE LEARNING

Sajidan, Afandi

CULTURE-BASED EDUCATION TO FACE DISRUPTION ERA

Siti Irene Astuti Dwiningrum

IMPLEMENTATION OF DISCIPLINE CHARACTER EDUCATION WITH CONTEXTUALTEACHING LEARNING (CTL) MODEL IN LEARNING AT STATE $1^{\text {STELEMENTARY SCHOOL OF ADIKARSO KEBUMEN }}$

Afrida Conniestia Ikhsani, Nadya Vera Wibowo, Purwaka Atmaja, Rokhmaniyah

THE ROLE OF LITERACY ACTIVITIES ON INTELLECTUAL DEVELOPMENT OF CLASS 5 SDN BANJURMUKADAN THROUGH ANALYSIS OF DEVELOPMENT TASKS AND INVENTORY STUDENT DEVELOPMENT TASKS IN 2018

Amanda Putri Nurjanah, Febriyanti Umi Khabibah, Muhammad Chamdani

AN ANALYSIS OF CLASSROOM MANAGEMENT DIFFICULTIES IN THEMATIC LEARNING IN SD N 2 KUTOSARI

Ana Nur Fajriyati, Mutiara Anggun Puspitasari

E-LEARNING EQUIPMENT IN LEARNING PROCESSAT VOCATIONAL HIGH SCHOOL

Arif Wahyu Wirawan, Wahyudi

SELF-SUFFICIENCY THROUGH MODULE

Atika Dwi Evitasari

EFFECTIVENESS OF AL-BARQY METHOD IN IMPROVING THE ABILITY TO READ ARABIC BRAILLE ON STUDENTS IN GRADE 3 AT SDLB PUTRAMANUNGGAL GOMBONG

Budiono

PROFESSIONALISM OF LECTURERS TO IMPROVE CHARACTER OF THE MILLENNIAL STUDENT IN DISRUPTION ERA 
ANALYSIS OF CHARACTER VALUES THROUGH ITP AND ATP TECHNOLOGY AS ONE OF THE INNOVATIONS IN LEARNING ELEMENTARY SCHOOL EDUCATION TO OVERCOME DEGRADATION

Cut Nurul Zara Vonna, Fenti Retnoningrum, Indah Novita Sari, Muhamad Chamdani

INNOVATION EDUCATION IN THE WRITING OF SCIENTIFIC PAPERS

Deti Rostini, Ade Tutty Rokhayati Rosa

URGENCE OF SAINTIFIC-BASED INQUIRY IMPLEMENTATION IN IMPROVING STUDENT'S CRITICAL THINKING ABILITY

Devi Afriyuni Yonanda, Yuyun Dwi Haryanti

ANALYSIS OF THE APPLICATION OF COOPERATION AND IMPROVEMENT OF STORYTELLING SKILLS IN LEARNING ELEMNETARY SCHOOL STUDENTS

Dian Sindi Nofianti, Kartika Chrysti Suryandari

A SHORT STORY READING SECTION AS AN ALTERNATIVE WAY TO IMPROVE STUDENT'S LITERACY IN SD N 6 PANJER KEBUMEN

Dwi Novitasari, Eka Fajriatul Janah, Muhamad Chamdani

THE INFLUENCE OF SEX TOWARD THE COMPREHENSION READING ABILITY OF CLASS V STUDENTS IN THE ELEMENTARY SCHOOL OF PANJER VILLAGE

Dwi Pungky Ari Sandhi, Diyani Ayu Karimizzah, Diah Monitasari, Suhartono

OPTIMIZATION OF THE LIBRARY FOR SCHOOL LITERACY MOVEMENT Dwi Purwanti

THE IMPLEMENTATION OF THE LITERACY MOVEMENT THROUGH THE SCHOOL PROGRAM "RaYa KaTa" and "PerSis SiPil"

Dwi Wahyuning Aisyah, Joharman

THE ANALYSIS OF INFORMATION LITERACY SKILL THROUGH APLLICATION THE BIG 6 MODELS ON COLLEGE STUDENTS OF PGSD UNS KEBUMEN YEAR 2017

Eko Andri Susilo, Istinganatuzzakiyah, Lhinatul Arivvia Rachma, Ratna Hidayah

THE ROLE OF READING ROOM AT PGSD UNIVERSITAS SEBELAS MARET IN SUPPORTING THESIS PROCESS FOR STUDENTS

Eli Sari Utami, Pulung Ardianto, Miftakhus Salami, Laras Mahmudah

CHARACTER VALUES IN MACAPAT SONG

Ellie Syafitri, Hanaan Rofiiqoh, Rifa Alimah, Muhamad Chamdani

PROBLEM SOLVING: INTRODUCTION OF SCIENCE LEARNING IN ELEMENTARY SCHOOL

Fatchul Fauzi

SELF-EFFICACY ANALYSIS OF SIXTH GRADE MATHEMATICS LEARNING OUTCOMES IN SD N 7 KEBUMEN

Febriana Setyowati, Susilaily Rahmawati, Kartika Chrysti Suryandari 
HABITUATION TO SIGNING CHILDREN'S SONGS TO EMBED CHARACTER VALUES IN LOW GRADE STUDENTS OF SDN 1 DEPOKREJO

Heni Rahmawati, Anjar Wijiatmiko, Novia Indrianingsih, Rokhmaniyah

IMPLEMENTATION OF CHARACTER EDUCATION VALUES IN ISLAMIC SCHOOL INTEGRATED TO IBNU ABBAS KEBUMEN

Indri Novianti, Lutfiana Rahmayanti, Rizki Isnaeni Putri, Siti Fatimah

TRADITIONAL GAME (GAPYAK) AS EFFORT TO DEVELOP COMMUNICATION AND STUDENT COOPERATION IN 1 BUMIREJO ELEMENTARY SCHOOL

Ingtiarti, Nur Rofiqoh, Ivan Arifudin, Kartika Chrysti Suryandari

ERROR ANALYSIS OF STUDENTS IN GRADE VI OF BUMIREJO 208-216 ELEMENTARY SCHOOL 1 IN COMPLETING FLOWCHART DEBIT STORY PROBLEMS

Isni Ramadhantri, Andhi Achmad, Arvrian Sukoco, Kartika Crysti Suryandari

DEVELOPMENT OF ECO-CULTURE TO IMPROVE ENVIROMENTAL LITERACY IN ELEMENTARY SCHOOL

Karenina Shashal Agsari, Mayang Kusumaning Rahady, Wahyudi

COLLABORATIVE ACADEMIC SUPERVISION TO IMPROVE INSTRUCTIONAL COMPETENCY IN IMPLEMENTATION CURRICULUM 2013 IN ALIAN DISTRICT Karsiyem

INCREASING ACTIVITY AND LEARNING OUTCOMES OF MATHEMATICS ABOUT FRACTIONS THROUGH MATHEMATICAL LITERACY IN CLASS VI STUDENTS OF SD NEGERI NAMPUDADI

Komariyah

THE DEVELOPMENT OF TEACHING MATERIALS BASED ON LOCAL WISDOM IN JIGSAW LEARNING MODEL FOR DESCRIPTION WRITING SKILLS

Krisna Anggraeni, Devi Afriyuni Yonanda

THE CORRELATION OF READING INTEREST TO LEARNING OUTCOMES IN INDONESIAN LEARNER IN CLASS 5 of SDN 2 KARANG TANJUNG

Laras Tazkiatul Amanah, Rizki Noviana, Rodatus Sofiah, Muhamad Chamdani

ANALYSIS OF THE APPLICATION OF BASIC TEACHING SKILLS AS PROFESSIONAL DEVELOPMENT EFFORTS FOR TEACHER IN ELEMENTARY SCHOOL

Leny Retno Indriani, Kurnia Indrawati, Khafidatun Nafi'ah, Tri Saptuti Susiani

ANALYSIS OF JAVANESE LANGUAGE VOCABULARY SKILL FOR 263-268 ELEMENTARY SCHOOL STUDENTS IN KEBUMEN DISTRICT

Liftahul Sekar Aji, Sugiharti, Moh Salimi

ETHNOMATHEMATICS AN ALTERNATIVE IN THE DEVELOPMENT OF 269-273 MULTICULTURAL EDUCATION AT THE PRIMARY SCHOOL

Mahpudin, Liyana Sunanto

ANALYSIS OF CRITICAL THINKING IN CLASS 4 STUDENTS OF SDN 2 KUTOSARI IN THEMATIC LEARNING 2013 CURRICULUM

Marchelina Dwi Saputri, Kartika Chrysti Suryandari 
SCHOOL LITERACY MOVEMENT THROUGH READING ANGLE OPTIMIZATION IN CLASSES TO IMPROVE STUDENT READING INTEREST Maya Jayanti, Rachma Mutiara Dewi, Zahrotun Nafi', Moh Salimi

PROFILE IMPLEMENTATION OF INCLUSIVE EDUCATION IN ELEMENTARY SCHOOL AT KEBUMEN

Muhamad Chamdani

THE CONSTRAINTS ANALYSIS OF IMPLEMENTING SCHOOL LITERACY MOVEMENT AT SDN 2 KALIBENING

Nashri Maulidah, Neni Dewi Anggraeni, Tria Mugi Safitri, Siti Fatimah

THE LEGEND OF "GUNUNG WURUNG" AS LOCAL WISDOM FOR TEACHING MATERIALS AND CHARACTER EDUCATION IN ELEMENTARY SCHOOL

Ngatman, Siti Fatimah

BUILD RELIGIOUS CHARACTER THROUGH 5S (SENYUM, SAPA, SALAM, SOPAN, SANTUN)

Nita Eka Rahmawati, Ngaenu Rofiqoh, Lutfia Islahati, Moh Salimi

CONCEPT AND IMPLEMENTATION OF THE WHOLE LANGUAGE APPROACH IN INDONESIA LANGUAGE LEARNING

Novita Donna Zamzami, Novi Nurhayati, Moh Salimi

APPLICATION OF SCHOOL LITERACY MOVEMENT PROGRAM (GLS) IN ELEMENTARY SCHOOL MATHEMATICS LEARNING

Novy Trisnani

CHARACTER BUILDING BASED ON LOCAL WISDOM IN THE FILM TITLED TANDA TANYA “?"

Nur Alfi Farikhah, Ratna Handayani Pramukti, Vena Nur Litasari, Ratna Hidayah

DEVELOPMENT OF MULTIMEDIA LEARNING SCIENCE FOR PRIMARY SCHOOLS BASED ON CONSTRUCTIVISTIC LEARNING THEORY

Nur Ngazizah, Titi Anjarini

THE ROLE OF LIBRARY IN DEVELOPING LITERACY OF SD N 4 KUTOSARI STUDENT

Nurjihan Hasanah, Listiyani, Solikhatun Diniah, Ratna Hidayah

THE USE OF THE SCHOOL LIBRARY AT THE ELEMENTARY SCHOOL SD NEGERI 2 PEJAGOAN

Nurul Safitri, Tri Purna Widiyani, Umi Hanifah, Ratna Hidayah

ANALYSIS OF CREATIVE THINKING ABILITY IN THE IMPLEMENTATION OF THEMATIC LEARNING IN CLASS V STUDENTS OF SD N 1 PANJER ACADEMIC YEAR 2018/2019

Peni Setyorini, Nurhasanah, Kartika Chrysti Suryandari

DEVELOPMENT MODELOF TRADITIONAL GAME (GONTENG) AS PHYSICAL EDUCATION LEARNING IN CHARACTER BUILDING FOR UPPER CLASS ELEMENTARY SCHOOL STUDENTS

Puput Widodo, Ibnu Prasetyo Widiyono, Yogi Ferdy Iriawan

280-285

286-291

292-297

298-307

308-313 
ANALYSIS OF LEARN DISCIPLINE IN IMPLANTATION CHARACTER EDUCATION OF IVA STUDENTS AT SD NEGERI 5 PANJER IN 2018

Rokhmaniyah, Risma Mila Ardila

IMPLEMENTATION OF THEMATIC LEARNING IN THE SD N 6 PANJER KEBUMEN

Septy Dewi Purwanti, Eka Setya Septiningrum, Akbar Maulana Hidayat, Ratna Hidayah

DEVELOPING PANCOH ECOTOURISM-ORIENTED THEMATIC STRIP COMICS FOR ELEMENTARY SCHOOL STUDENTS

Shanta Rezkita, Latifatun Mukaromah

MULTILITERATION PEDAGOGIC MODEL BASED ON HIGHER ORDER THINKING SKILL (HOTS) AS EFFORTS TO FACE THE 21st CENTURY EDUCATION IN EDUCATION FROM KI HADJAR DEWANTARA

Sigit Vebrianto Susilo, Ari Yanto

THE RELATIONSHIP BETWEEN READING SPEED AND READING COMPREHENSION IN INDONESIAN SUBJECTS IN V GRADE ELEMENTARY SCHOOL

Siti Badriyah, Rina Yuliana

FAIRY TALE STORIES AS THE CULTURAL GROWER OF LITERACY READING FOR PRIMARY SCHOOL STUDENTS

Siti Mustakimah, Maulida Ajeng Priyatnomo, Muhamad Chamdani

INVESTIGATING ENVIRONMENTAL CONCERNS FOR PRIMARY SCHOOL TEACHERS

Siti Patonah, Sentot Budi Rahardjo, Cari, Sajidan

ANALYZE THE INDEPENDENCE OF CLASS VI STUDENT LEARNING ON SCIENCE SUBJECT IN SD NEGERI 5 KEBUMEN

Sittah Amrina Rosyada, Erlina Hanita Irawati, Kartika Christy Suryandari

IMPLEMENTATION OF CTL MODELS WITH PLASTISIN MEDIA TOWARDS COGNITIVE MAPPING OF STUDENTS IN BASIC SCHOOL LEARNING

Siwi Utaminingtyas

PARTNERSHIP OF SCHOOL-FAMILY-COMMUNITIES AND ITS EFFECT ON STUDENT LEARNING OUTCOMES IN ELEMENTARY SCHOOL KEBUMEN

Suhartono, Ngatman, Tri Saptuti Susiani, Ratna Hidayah

ANALYSIS OF TEACHERS DIFFICULTY BASED ON 2013 CURRICULUM IMPLEMENTATION IN ELEMENTARY SCHOOL 1 KALIJOYO ALIAN DISTRICT KEBUMEN REGENCY

Syifa Khoerunnisa, Maria Ulfah, Purwoko Aji Prasetyo, Kartika Chrysti Suryandari

COMIC LEARNING MEDIA DEVELOPMENT IN EFFORTS TO GROW LITERACY CULTURE AND ENVIRONMENTAL CARE ATTITUDE FOR ELEMENTARY SCHOOL STUDENT

Syifa' Lana, Rifqi Aulia Rahman, Rudi Danang Widodo, Siti Fatimah 
ANALYSIS OF THEMATIC LEARNING IN THE 2013 CURRICULUM SDN 7 KEBUMEN

Teguh Rahayu, Kurnia Wardani Putri, Isnaeniatun Umifaiqoh, Kartika Chrysti Suryandari

RESEARCH BASED LEARNING (RBL) TO IMPROVE CRITICAL THINKING SKILLS

Tiyara Mahardini, Firdaus Khaerunisa, Indah Wahyu Wijayanti, Moh Salimi

IMPLEMENTATION OF COLLAGE SKILLS ON EARLY CHILDHOOD 474-479 CREATIVITY

Tri Saptuti Susiani, Maulida Ajeng Priyatnomo, Laras Tantifah

CREATIVE CHARACTER EDUCATION IN THE UTILIZATION OF USED GOODS INTO VERTICULTURE IN CLASS IV SDN 7 KUTOSARI KEBUMEN

Tri Saptuti Susiani, Noviatun Khasanah

THE CLINICAL SUPERVISION MODEL WITH CLASS ACTION APPROACH OF MICROTEACHING PROGRAM IN THE FKIP OF PGRI MADIUN UNIVERSITY V. Teguh Suharto, Dwi Setiyadi, Elly's Mersina Mursidik, Ermi Adriani Meikayanti

PROBLEMS WITH THE 2013 CURRICULUM CHANGE ON THE QUALITY OF TEACHER TEACHING

Wahyu Pramesti, Mauliddhina Imas Permatasari, Muhamad Chamdani

DEVELOPMENT OF STUDENT DISCIPLINE CHARACTER EDUCATION THROUGH CEREMONY ACTIVITIES AT BUMIREJO STATE ELEMENTARY SCHOOL

Wahyu Retnoningsih, Wahyu Khasanah, Muhamad Chamdani

MENTORING OF CLASSROOM ACTION RESEARCH AND PUBLICATION OF SCIENTIFIC WORKS IN DEVELOPMENT OF SUSTAINABLE PROFESSION FOR ELEMENTARY SCHOOL TEACHERS

Wahyudi, Rokhmaniyah, Kartika Chrysti Suryandari

FACILITATING LEARNING STYLES IN ELEMENTARY SCHOOL STUDENTS Widia Indra Kartika, Syifa Lailatul Mutmainnah, Nurlia Agustina, Moh Salimi

LEARNING MODEL BASED ON PANDE TRADITIONAL GAME TO STRENGTHEN STUDENT CHARACTERS

Yuniatun Dwi Nurriskah, Idzaa Zubdatun Thoyyibah, Muhamad Chamdani

LITERACY COMPETENCE AND HIGH ORDER THINKING SKILLS IN 527-532 CURRICULUM 2013 IMPLEMENTATION

Yuyu Yuliati, Dudu Suhandi Saputra

IMPLEMENTATION OF DIGITAL LITERACY IN SOCIAL SCIENCES EDUCATION ELEMENTARY SCHOOL WITH WAYANG MEDIA FOR STKIP BINA INSAN MANDIRI PGSD STUDENTS

Zuni Eka Tiyas Rifayanti, Evi Rizki Salamah 
APPLICATION OF "MAKE A MATCH" LEARNING MODELS WITH COLOR $543-550$ CARD MEDIA TO IMPROVE MOTIVATION AND THE RESULT OF CIVIL EDUCATION LEARNING ABOUT STATE INSTITUTIONS IN VI CLASS STUDENTS IN SD NEGERI ADITIRTO KECAMATAN PEJAGOAN, KEBUMEN DISTRICT

Suratman 